\title{
Effect of underground salty mine water on the rotifer communities in the Bolina River (Upper Silesia, Southern Poland)
}

\author{
Dariusz Halabowski ${ }^{*}$, Irena Bielańska-Grajner and Iga Lewin \\ Department of Hydrobiology, Faculty of Biology and Environmental Protection, University of Silesia, 9 Bankowa Street, \\ 40-007 Katowice, Poland
}

Received: 11 March 2019 / Accepted: 22 May 2019

\begin{abstract}
The research was carried out in the Bolina River, which is the most anthropogenically saline river in Europe, from 2017 to 2018. This river flows through the highly industrialised and urbanised part of Upper Silesia (Poland). The aims of our survey were to analyse the structure of the rotifer communities and to determine the most important environmental factors that have a significant impact on their structure in a river under the influence of underground salty mine water discharge. According to a canonical correspondence analysis (CCA), the rotifer communities in the Bolina River are affected by electrical conductivity, the temperature of the water and the concentration of phosphates. An increase in the electrical conductivity (salinity) in the lower course, which was the result of salty mine water discharge into the Bolina River, was reflected by a decrease in the median density, the number of rotifer taxa and the Shannon-Wiener index $H^{\prime}$. The Bolina River is a unique habitat for halophilic rotifers as well as a site of the occurrence of rotifers that can also develop in winter.
\end{abstract}

Keywords: Coal mine waters / river salinisation / Rotifera / species diversity

Résumé - Effet de l'eau souterraine de mines de sel sur les communautés de rotifères dans la rivière Bolina (Haute Silésie, Sud de la Pologne). La recherche a été menée de 2017 à 2018 dans la rivière Bolina, qui est la rivière la plus saline d'Europe d'un point de vue anthropogénique. Ce fleuve traverse la partie hautement industrialisée et urbanisée de la Haute-Silésie (Pologne). L'objectif de notre étude était d'analyser la structure des communautés de rotifères et de déterminer les facteurs environnementaux les plus importants qui ont un impact significatif sur leur structure dans une rivière sous l'influence d'un déversement souterrain d'eau salée de mine. Selon l'analyse canonique des correspondances (CCA), les communautés de rotifères de la rivière Bolina sont affectées par la conductivité électrique, la température de l'eau et la concentration en phosphates. Une augmentation de la conductivité électrique (salinité) dans le cours inférieur, résultat d'un rejet d'eau salée dans la rivière Bolina, s'est traduite par une diminution de la densité médiane, du nombre de taxons de rotifères et de l'indice Shannon-Wiener $H^{\prime}$. La rivière Bolina est un habitat unique pour les rotifères halophiles ainsi qu'un site d'occurrence de rotifères qui peuvent aussi se développer en hiver.

Mots clés : Eaux de mines / salinisation des rivières / Rotifera / diversité spécifique

\section{Introduction}

Hard coal mining requires the discharge of underground mine waters into settling ponds or, more rarely, directly into rivers. The waters that are discharged from hard coal mines contain a very large amount of ions, which is reflected by the high values of total dissolved solids (TDS) and electrical

\footnotetext{
*Corresponding author: dhalabowski@us.edu.pl
}

conductivity (EC). In this type of mine waters, the concentrations of chlorides, sulphates, phosphates, nitrates, heavy metals and often radioactive substances is relatively high (Harat and Grmela, 2008; Cañedo-Argüelles et al., 2013). Discharge of mine water into freshwater environments along with anthropogenic climate changes (an increase in extreme temperatures or droughts) are the reasons for the changes in the physical and chemical characteristics of these environments. According to the IPCC report (Masson-Delmotte et al., 2018), in order not to exceed the safe limit for climate change, i.e. an 
average increase in temperature of $1.5^{\circ} \mathrm{C}$ by the end of the 21st century, global $\mathrm{CO}_{2}$ emissions must decrease by about $45 \%$ by 2030 compared to the emissions of the 2010 s, which would mean, e.g. closing coal mines. Moreover, coal combustion should be discontinued, which would require the total abandonment of coal by 2050 . By contrast, a report (Bukowski et al., 2013) concerning the Polish climate policy does not require limiting coal mining and coal burning in Poland until 2030. In addition, regardless of whether hard coal mines are open or closed, the discharge of underground mine waters from the mine dewatering systems into the surface waters must be continued in order to mitigate the risk of the flooding of underground mine workings. This will lead to the further pollution of inland waters by salty water from coal mines, which, in addition to the threats due to climate change in sensitive regions, is a real threat to biodiversity.

Minor changes in the salinity of water result in other factors that affect aquatic invertebrates, e.g. the velocity of the water and the concentration of nutrients (Williams, 2001). The strong salinisation of inland waters alters the natural characteristics of aquatic ecosystems, limits the distribution of aquatic invertebrates and decreases biodiversity. A high concentration of salts in the water is toxic to freshwater organisms and affects their basic physiological and biological functions (Williams, 1987, 2001; Hammer, 1993; Tiwary, 2001; Derry et al., 2003; Pinder et al., 2005; Jin, 2008). Rotifera are very sensitive to salinity, and therefore, a considerably higher number of rotifer species inhabits freshwater environments (Remane and Schlieper, 1971; Wallace and Snell, 2001; Fontaneto et al., 2006). An increase in the salinity of water causes changes in rotifer populations and affects their diversity and dynamics (Akopian et al., 2002; Sarma et al., 2006). Therefore, among the more than 2000 Rotifera species that have been described, only a few are able to tolerate brackish and salty waters (Miracle and Serra, 1989; Onwudinjo and Egborge, 1994; Fontaneto et al., 2006; Segers, 2007; Zakaria et al., 2007).

The rotifer communities of inland waters that are under the strong pressure of mine waters have been a rare subject of interest for scientists. Planktonic rotifers have primarily been studied in a secondary sedimentation pond with brackish water, settling ponds and mine pit lakes in Poland (Bielańska-Grajner and Cudak, 2014; Goździejewska et al., 2018; Pociecha et al., 2018) and other areas of the world that have both natural and secondary salinity (ponds, lakes, and rivers) (Hammer, 1993; Derry et al., 2003; Schallenberg et al., 2003; Pinder et al., 2005; Jin, 2008; Nielsen et al., 2008; Walsh et al., 2008; Arora and Mehra, 2009; Kaya et al., 2010; Pociecha and Bielańska-Grajner, 2015). To date, a survey on the ecology of rotifer communities that are under a high impact of anthropogenic salinisation of running waters has not been carried out. In contrast, research on rotifers in saline running waters has been limited only to estuaries (Medeiros et al., 2010; Abdul et al., 2016).

The aims of our survey were to analyse the structure of rotifer communities and to determine the most important environmental factors that have a significant impact on their structure in a river under the influence of underground salty mine water discharge. We hypothesised that a higher concentration of the ions that are present in the post-mining water in the lower course of the river reflected by a higher electrical conductivity, would affect the composition of rotifer species and density more strongly than in the upper course of the river, which has a lower concentration of these ions.

\section{Materials and methods}

The research was carried out in the most anthropogenically saline river in Europe, i.e. in the Bolina River in 2017-2018. This river flows through the highly industrialised and urbanised part of Upper Silesia (Southern Poland) (Fig. 1). The Bolina River has a total length that does not exceed $11 \mathrm{~km}$ and a catchment area of $29.52 \mathrm{~km}^{2}$. The European Union Water Framework Directive (Directive, 2000) classifies streams and rivers into different types in terms of abiotic variables. The following criteria (system A) are used in the classification: ecoregion, size of the catchment area (small, medium, large and very large), geology of catchment area (calcareous, siliceous and organic) and altitude (high, mid-altitude and lowland). According to above criteria, the Bolina River is a mid-altitude siliceous stream that has a fine-particulate substratum (abiotic type 5). The Bolina River is a secondary tributary of the Vistula River, which is one of the longest rivers in Europe. Two sampling sites were selected-one that was located in the upper course and the second that was located in the lower course of the Bolina River. The Bolina River has its sources in a forested area. It flows through the forested and then urbanised areas along a motorway and other roads. Starting at its source, the Bolina River is contaminated with salty mine waters from the "Murcki-Staszic" hard coal mine. The sampling site in the upper course of the Bolina River is located between a railway embankment and the Bolina Park. The right bank of the river is overgrown with trees, while a dam reservoir is located on the left bank. The catchment area from the source to the sampling site in the upper course is approximately $9.8 \mathrm{~km}^{2}$. Underground salty mine waters are discharged into the river between the upper and lower courses. The Bolina River then flows through heavily built-up areas and wastelands, in which the second sampling site is located (lower course). The distance between the sampling sites is $2.35 \mathrm{~km}$. The catchment area from the source to the sampling site in the lower course is approximately $19.7 \mathrm{~km}^{2}$. In addition to the underground salty mine water discharges, small streams also feed into the Bolina River. The entire bed of the Bolina River is regulated.

The width of the riverbed, the depth and the flow velocity were measured in the field. The samples were collected four times in 2017 (once in spring, twice in summer, once in autumn) and once in 2018 (in winter). The samples of rotifers were collected at two different sites using quantitative methods, i.e. in the lower course (N 50 14.742'; E $19^{\circ} 06.078^{\prime}$ ) and in the upper course (N 50 $13.793^{\prime}$; E $\left.19^{\circ} 05.142^{\prime}\right)$ from various microhabitats: open water, macrophytes (Enteromorpha sp. and Phragmites australis) and diatom aggregations.

A total of 30 samples were collected (10 planktonic samples and 20 periphytic samples). The planktonic samples of rotifers were collected using the standard methods by pouring $20 \mathrm{dm}^{3}$ of water through a plankton net with a mesh size of $50 \mu \mathrm{m}$. At the upper and lower courses of the Bolina River, periphytic samples of rotifers were collected from different substrata (macrophytes and diatom aggregations) by 


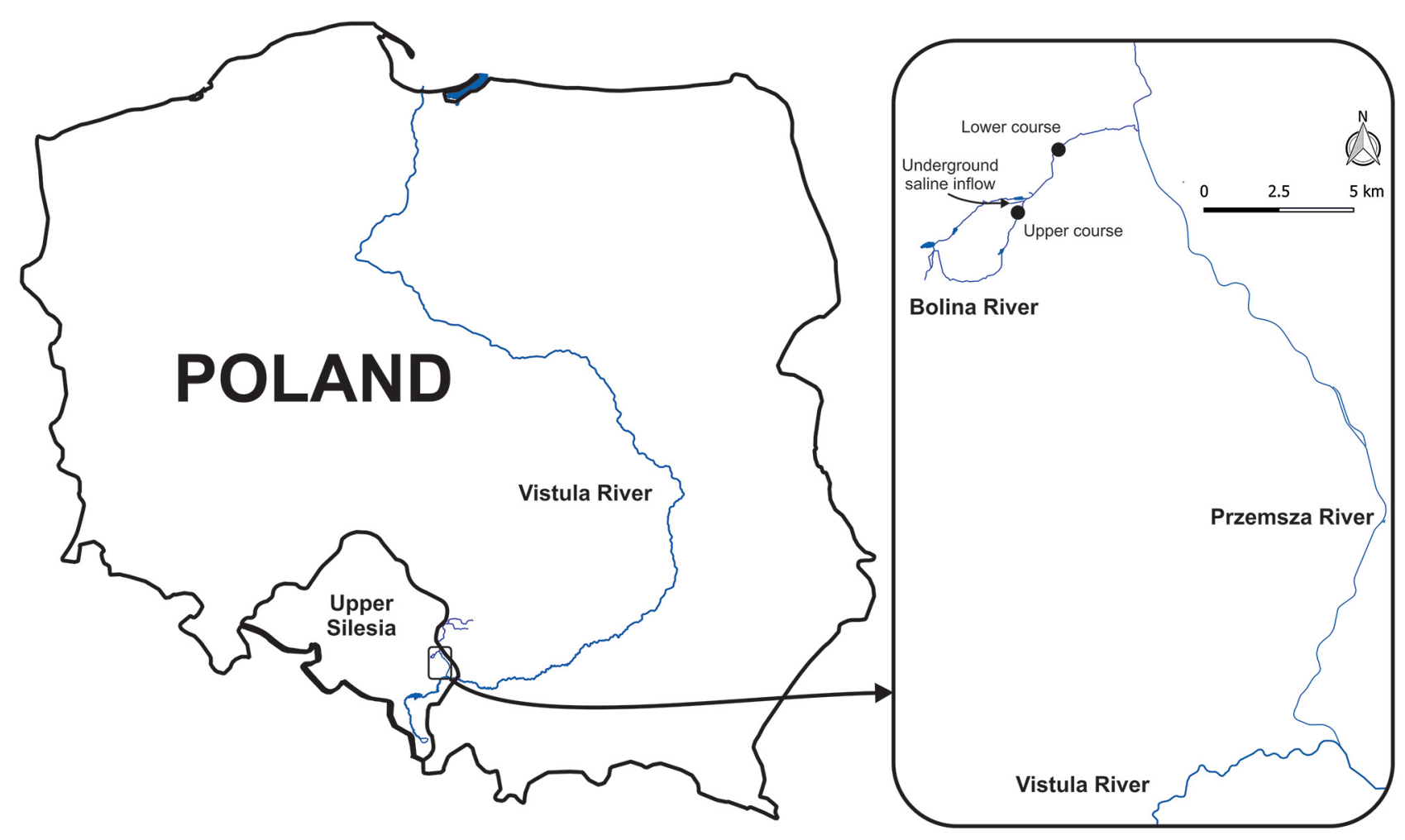

Fig. 1. Location of the study area.

cutting different fragments (a total of $25 \mathrm{~cm}^{2}$ for each surface total area of rotifer collection) of each plant (Enteromorpha sp. in the upper and lower courses of the Bolina River and Phragmites australis only in the upper course) and diatom aggregations (only in lower course) using a soft toothbrush (Chindah, 2004; Tarkowska-Kukuryk, 2013). The material was fixed with Lugol fluid and preserved in a formalin solution (4\%). The rotifer species were classified according to Segers (2007) and identified according to Bielańska-Grajner et al. (2014b, 2015).

Water for physical and chemical measurements was collected at the same sites as the rotifers. The electrical conductivity (EC), total dissolved solids (TDS), dissolved oxygen and temperature were measured in the field using Hanna Instruments and Elmetron portable meters. The concentrations of $\mathrm{Cl}^{-}, \mathrm{SO}_{4}{ }^{2-}, \mathrm{NH}_{4}{ }^{+}, \mathrm{NO}_{2}{ }^{-}, \mathrm{NO}_{3}{ }^{-}, \mathrm{PO}_{4}{ }^{3-}, \mathrm{Ca}^{2+}, \mathrm{Mg}^{2+}$, salinity, total hardness and alkalinity were analysed in the laboratory according to Hermanowicz et al. (1999).

The structure of the rotifer communities was analysed using the following indices: dominance $(D \%)$, frequency $(F \%)$, density of rotifers (number of individuals per $10 \mathrm{~cm}^{3}$ in the planktonic samples or per $10 \mathrm{~cm}^{2}$ in the periphytic samples) (Górny and Grüm, 1981) and the Shannon-Wiener index $\left(H^{\prime}\right)$ (McCune and Grace, 2002). The values for the dominance index $(D \%)$ were divided into five classes: eudominants $>10.0 \%$ of a sample, dominants $5.1-10.0 \%$ of a sample, subdominants $2.1-$ $5.0 \%$ of a sample, recedents $1.1-2.0 \%$ of a sample and subrecedents $\leq 1.0 \%$ of a sample.

Canonical correspondence analysis (CCA) was performed to evaluate the relationships between the species composition of the rotifers and the environmental variables using CANOCO version 4.5 (Ter Braak and Šmilauer, 2002). The significance of the differences in the median values of the environmental variables between the upper and lower courses of the Bolina River was calculated using the Mann-Whitney $U$-test at a level of significance of $P<0.05$. The significance of the differences in the median number of the rotifer taxa, density and the values of the Shannon-Wiener index $\left(H^{\prime}\right)$ among the various types of microhabitats in the upper and lower courses of the Bolina River were calculated using the Kruskal-Wallis one-way ANOVA and multiple comparison post hoc tests using Statistica version 13.1.

\section{Results}

Very high values of EC (up to $46,600 \mu \mathrm{S} \mathrm{cm}^{-1}$ ), salinity (up to 33.55 PSU), TDS, total hardness and the concentrations of $\mathrm{Cl}^{-}$and $\mathrm{NH}_{4}^{+}$were recorded in the lower course of the Bolina River compared to the upper course (Tab. 1). The alkalinity and concentrations of $\mathrm{PO}_{4}{ }^{3-}$ and $\mathrm{SO}_{4}{ }^{2-}$ were higher in the upper course than in the lower course. The temperature of the water ranged from 9.10 to $28.60{ }^{\circ} \mathrm{C}$ in the upper course, whereas it ranged from 10.50 to $29.10{ }^{\circ} \mathrm{C}$ in the lower course. The results of the Mann-Whitney $U$-test $(P<0.05)$ showed significant differences in the median width, salinity, EC, TDS, total hardness and concentration of nitrites between the upper and lower courses of the Bolina River (Tab. 1).

A total of 11 taxa of rotifers were recorded in the Bolina River: nine taxa in the upper and lower courses (Tab. 2). Seven taxa were common for both sampling sites. Brachionus rubens was only recorded in the upper course of the Bolina River, whereas B. quadridentatus and Keratella quadrata occurred only in the lower course. A similar number of rotifer species 
D. Halabowski et al.: Knowl. Manag. Aquat. Ecosyst. 2019, 420, 31

Table 1. Physical and chemical parameters, velocity, morphometric features (minimum, median, maximum) of the Bolina River.

\begin{tabular}{|c|c|c|c|c|c|c|c|c|}
\hline \multirow[t]{2}{*}{ Parameter } & \multicolumn{3}{|c|}{ Upper course } & \multicolumn{3}{|c|}{ Lower course } & \multicolumn{2}{|c|}{ The Mann-Whitney $U$-test } \\
\hline & Min & Max & Median & Min & Max & Median & $U$-value & $p$-value \\
\hline Width of the river bed $(\mathrm{m})$ & 6.99 & 7.46 & 7.29 & 4.10 & 4.53 & 4.45 & -2.1651 & 0.0286 \\
\hline Depth of the river bed $(\mathrm{cm})$ & 25.17 & 29.67 & 26.90 & 20.20 & 25.90 & 22.69 & -1.5877 & 0.1143 \\
\hline Flow velocity $\left(\mathrm{m} \mathrm{s}^{-1}\right)$ & 0.06 & 0.42 & 0.13 & 0.40 & 0.56 & 0.47 & 1.8764 & 0.0571 \\
\hline Temperature $\left({ }^{\circ} \mathrm{C}\right)$ & 9.10 & 28.60 & 21.35 & 10.50 & 29.10 & 20.80 & -0.1443 & 1.0000 \\
\hline $\mathrm{pH}$ & 6.80 & 7.80 & 7.55 & 6.50 & 7.90 & 7.75 & 0.5774 & 0.4857 \\
\hline Salinity (PSU) & 6.57 & 12.25 & 9.71 & 16.34 & 33.55 & 23.29 & 2.1651 & 0.0286 \\
\hline Conductivity $\left(\mu \mathrm{S} \mathrm{cm}^{-1}\right)$ & 9130 & 17020 & 13490 & 22700 & 46600 & 32350 & 2.1651 & 0.0286 \\
\hline Total dissolved solids $\left(\mathrm{mg} \mathrm{dm}^{-3}\right)$ & 4570 & 8510 & 6745 & 11360 & 23300 & 16170 & 2.1651 & 0.0286 \\
\hline Chlorides $\left(\mathrm{mg} \mathrm{Cl}^{-} \mathrm{dm}^{-3}\right)$ & 1930 & 5590 & 4013 & 4800 & 17028 & 10655 & 1.5877 & 0.1143 \\
\hline Dissolved oxygen $\left(\mathrm{mg} \mathrm{O}_{2} \mathrm{dm}^{-3}\right)$ & 5.08 & 7.09 & 5.11 & 4.95 & 9.69 & 6.14 & 0.4330 & 0.6857 \\
\hline Sulphates $\left(\mathrm{mg} \mathrm{SO}_{4}^{2-} \mathrm{dm}^{-3}\right)$ & 352 & 560 & 430 & 320 & 524 & 386 & -0.1443 & 0.8857 \\
\hline 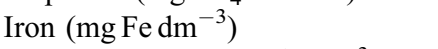 & 0.05 & 0.88 & 0.16 & 0.12 & 0.48 & 0.36 & 0.4330 & 0.6857 \\
\hline Ammonium $\left(\mathrm{mg} \mathrm{NH}_{4}^{+} \mathrm{dm}^{-3}\right)$ & 0.62 & 2.62 & 0.84 & 1.25 & 12.12 & 4.53 & 1.5877 & 0.1143 \\
\hline Nitrites $\left(\mathrm{mg} \mathrm{NO}_{2}{ }^{-} \mathrm{dm}^{-3}\right)$ & 0.66 & 1.44 & 0.97 & 2.30 & 9.96 & 3.64 & 2.1651 & 0.0286 \\
\hline Nitrates $\left(\mathrm{mg} \mathrm{NO}_{3}{ }^{-} \mathrm{dm}^{-3}\right)$ & 0.00 & 7.09 & 0.22 & 4.43 & 31.01 & 7.53 & 1.5877 & 0.1143 \\
\hline Phosphates $\left(\mathrm{mg} \mathrm{PO}_{4}{ }^{3-} \mathrm{dm}^{-3}\right)$ & 0.04 & 0.30 & 0.13 & 0.06 & 0.17 & 0.09 & 0.1143 & 0.6857 \\
\hline Total hardness $\left(\mathrm{mg} \mathrm{CaCO} 3 \mathrm{dm}^{-3}\right)$ & 1071.60 & 1920.00 & 1372.40 & 2268.20 & 4857.92 & 2862.98 & 2.1651 & 0.0286 \\
\hline Alkalinity $\left(\mathrm{mg} \mathrm{CaCO}_{3} \mathrm{dm}^{-3}\right)$ & 300 & 380 & 345 & 230 & 320 & 295 & -1.5877 & 0.1143 \\
\hline Calcium $\left(\mathrm{mg} \mathrm{Ca}^{2+} \mathrm{dm}^{-3}\right)$ & 328 & 687 & 406 & 416 & 1310 & 602 & 1.2990 & 0.2000 \\
\hline Magnesium $\left(\mathrm{mg} \mathrm{Mg}^{2+} \mathrm{dm}^{-3}\right)$ & 124 & 270 & 177 & 225 & 670 & 383 & 1.2990 & 0.5933 \\
\hline
\end{tabular}

The Mann-Whitney $U$-test; statistically significant differences in the medians are in bold.

was found in both the planktonic and periphytic samples, although one more species was found on the macrophytes (including the diatom aggregations). B.plicatilis was eudominant in the rotifer communities of the planktonic samples in both the lower and upper courses of the Bolina River (Tab. 2). B.rubens was a subdominant in the rotifer communities of the planktonic samples in the upper course. Colurella adriatica was a eudominant in the rotifer communities of the planktonic samples in the upper course, whereas it was a subrecedent of the planktonic samples in the lower course. Both C.colurus and C.adriatica were eudominants in the rotifer communities of the periphytic samples in the upper and lower courses, while Cephalodella catellina was a eudominant of the periphytic samples in the upper course. Higher values of the frequency index $(F \%)$ were obtained for rotifers of the Colurella genus, i.e. C. adriatica and C. colurus in the upper course and C. colurus and B. plicatilis in the lower course (Tab. 2).

The median number of rotifer taxa was higher in the upper course compared to the median number of rotifer taxa in the lower course (Fig. 2). The highest median density of 400 individuals per $10 \mathrm{~cm}^{2}$ was recorded for the rotifers in the periphytic samples in the upper course (Fig. 3). The median densities of the rotifers in the periphytic samples were higher than the median densities of the rotifers in the planktonic samples. The maximum density of the rotifers in the periphytic samples was 2080 individuals per $10 \mathrm{~cm}^{2}$, whereas the maximum density of the rotifers in the planktonic samples was 79 individuals per $10 \mathrm{~cm}^{3}$ (the lower course). The Kruskal-Wallis one-way ANOVA and multiple comparison post hoc tests revealed statistically significant differences in the median values of rotifer density $(H=11.4621 ; P=0.0095)$ at the sampling sites (Fig. 3). Significant differences were recorded among the median density of the planktonic rotifers in the upper and lower courses and the median density of the periphytic rotifers in the upper course. The values of the Shannon-Wiener index $\left(H^{\prime}\right)$ that was calculated for the periphytic and planktonic rotifer communities ranged up to 2.14 and 1.07 in the upper course and up to 1.73 and 0.51 in the lower course, respectively (Tab. 2). The maximum values of the $H^{\prime}$ index were higher for both the planktonic and periphytic rotifers in the upper course of the Bolina River compared to the lower course. The differences in the median values of the $H^{\prime}$ index that was calculated for the planktonic and periphytic rotifers were statistically significant at the sampling sites (the Kruskal-Wallis one-way ANOVA and multiple comparison post hoc tests $H=9.8975 ; P=0.0195$ ) (Fig. 4).

A canonical correspondence analysis (CCA) based on the rotifer data and environmental variables showed that the first and second axes explained $24.0 \%$ of the variance in the species data and $87.2 \%$ of the variance in the species and environment relationship. The temperature of the water, EC and the concentration of phosphates in the water were the parameters that were most associated (statistically significant according to the forward selection results) with the distribution of the rotifer taxa in the Bolina River (Fig. 5). The relationship between the species composition of the rotifers and the environmental variables was significant (Monte Carlo test of significance of the first canonical axis, $F$-ratio $=2.735, P$-value $=0.036$; test of significance of all of the canonical axes, $F$-ratio $=2.026$, $P$-value $=0.006)$. The CCA analysis showed that Brachionus plicatilis were associated with a higher water temperature and EC and a lower concentration of phosphates in the water. B. rubens, Cephalodella catellina and Bdelloidea n. det. were 
D. Halabowski et al.: Knowl. Manag. Aquat. Ecosyst. 2019, 420, 31

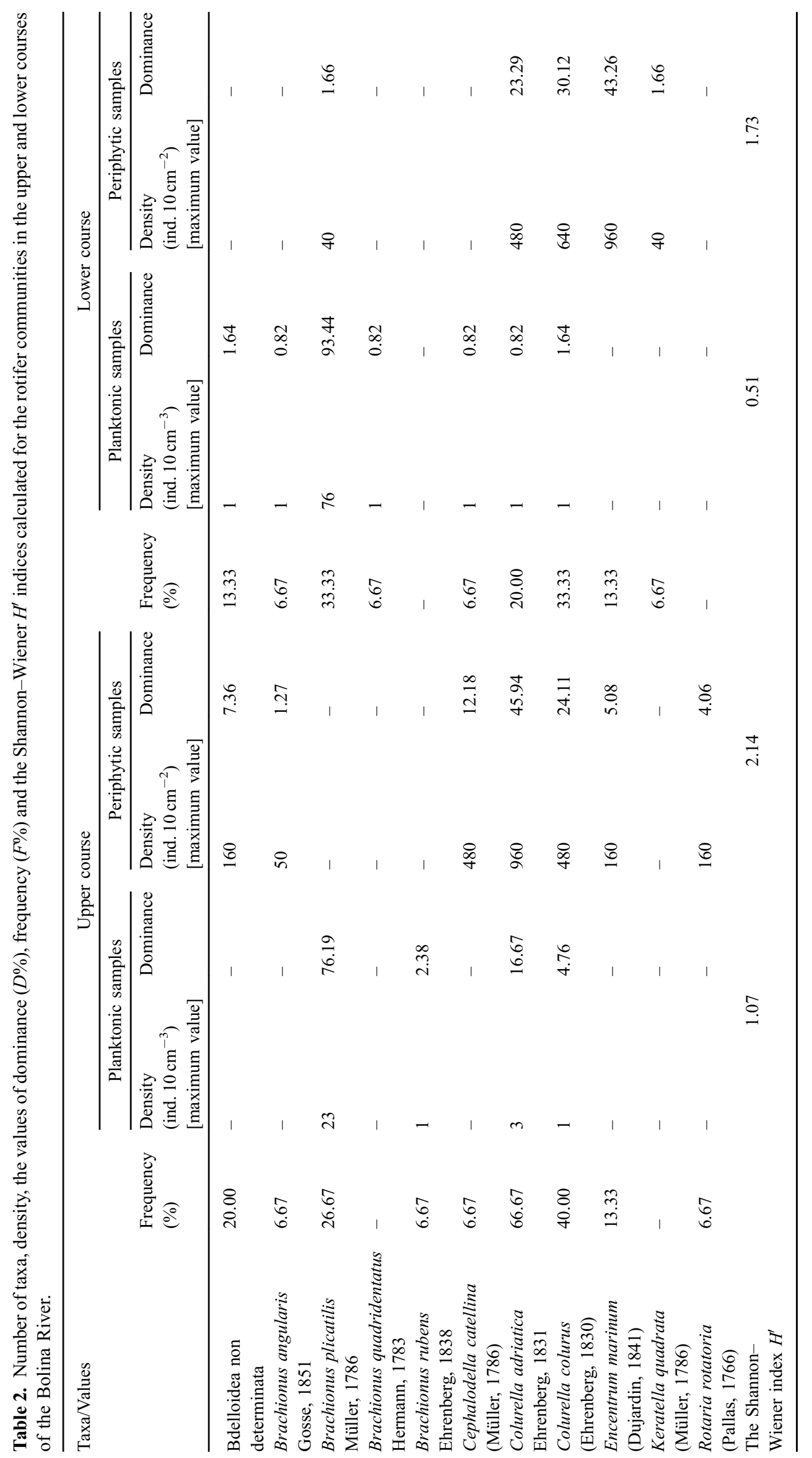




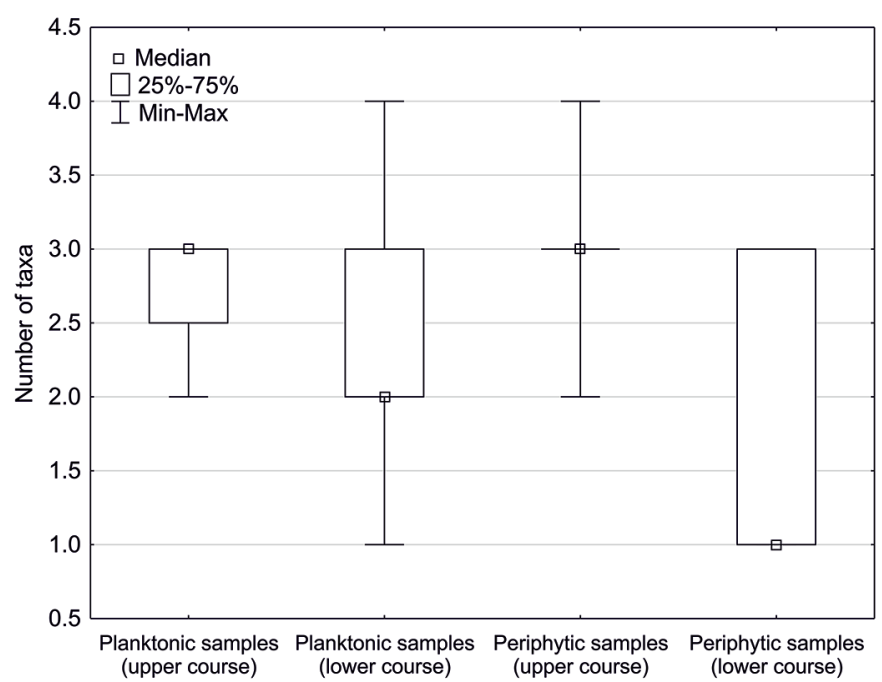

Fig. 2. Box-and-whisker plot showing the number of rotifer taxa (planktonic and periphytic samples) in the upper and lower courses of the Bolina River.

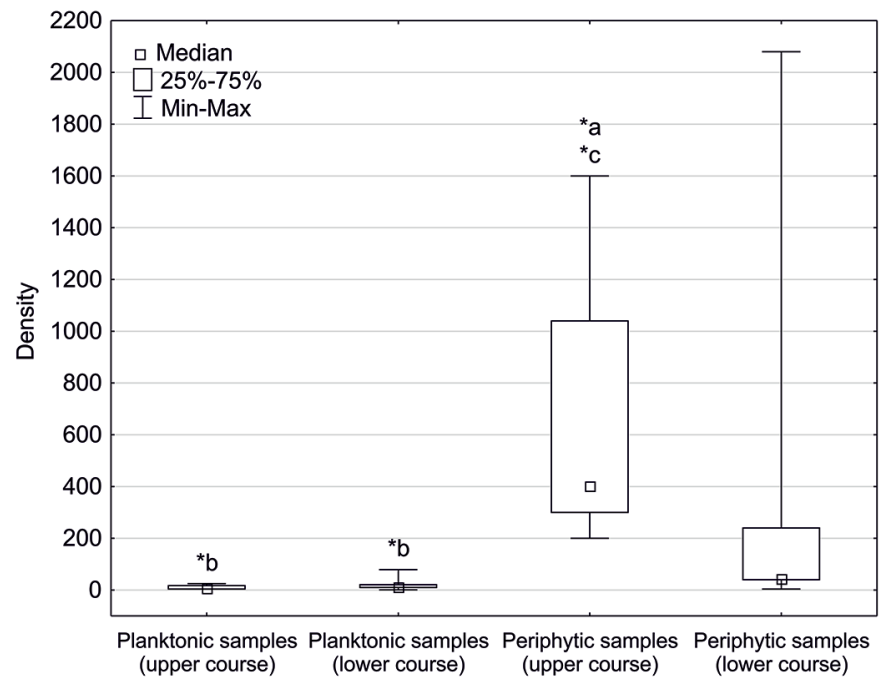

Fig. 3. Box-and-whisker plot showing the density of rotifers in planktonic (ind. $10 \mathrm{~cm}^{-3}$ ) and periphytic (ind. $10 \mathrm{~cm}^{-2}$ ) samples in the upper and lower courses of the Bolina River $\left({ }^{*}\right.$ Asterisks above a whisker denote significant differences, the Kruskal-Wallis one-way ANOVA and multiple comparison post hoc tests). Abbreviations: a: planktonic samples (upper course); b: periphytic samples (upper course); c: planktonic samples (lower course); d: periphytic samples (lower course).

associated with a higher water temperature and a lower concentration of phosphates. By contrast, Encentrum marinum and Colurella colurus were associated with a higher concentration of phosphates and a lower water temperature and a lower EC. C. adriatica was associated with a lower EC (Fig. 5).

\section{Discussion}

Knowledge about the rotifer communities in highly anthropogenically saline habitats is scarce and is limited only

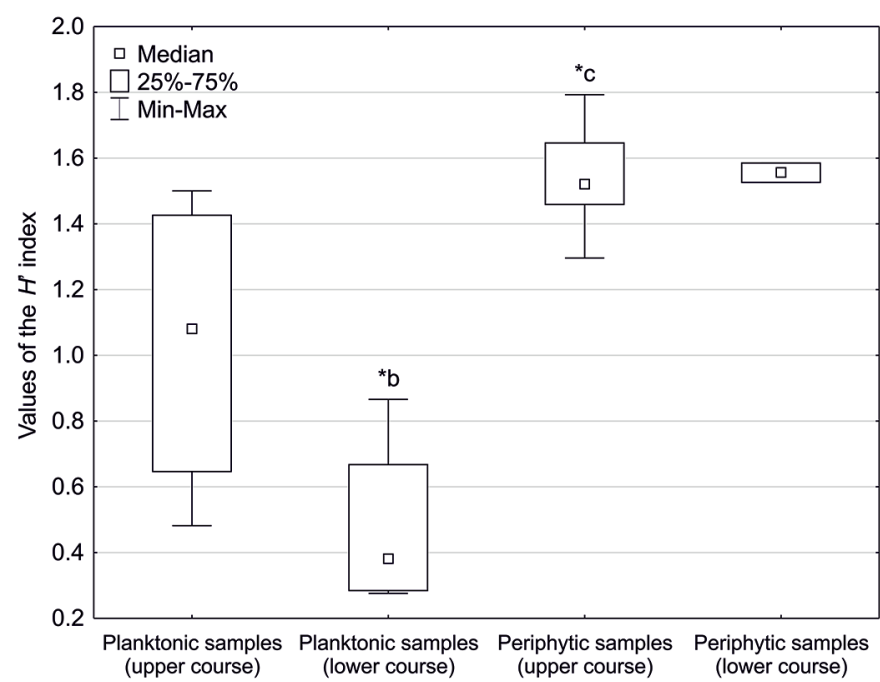

Fig. 4. Box-and-whisker plot showing the values of the ShannonWiener index $\left(H^{\prime}\right)$ calculated for the rotifer communities (planktonic, periphytic) in the upper and lower courses of the Bolina River (*Asterisks above a whisker denote significant differences, the Kruskal-Wallis one-way ANOVA and multiple comparison post hoc tests) (abbreviations: see Fig. 3).

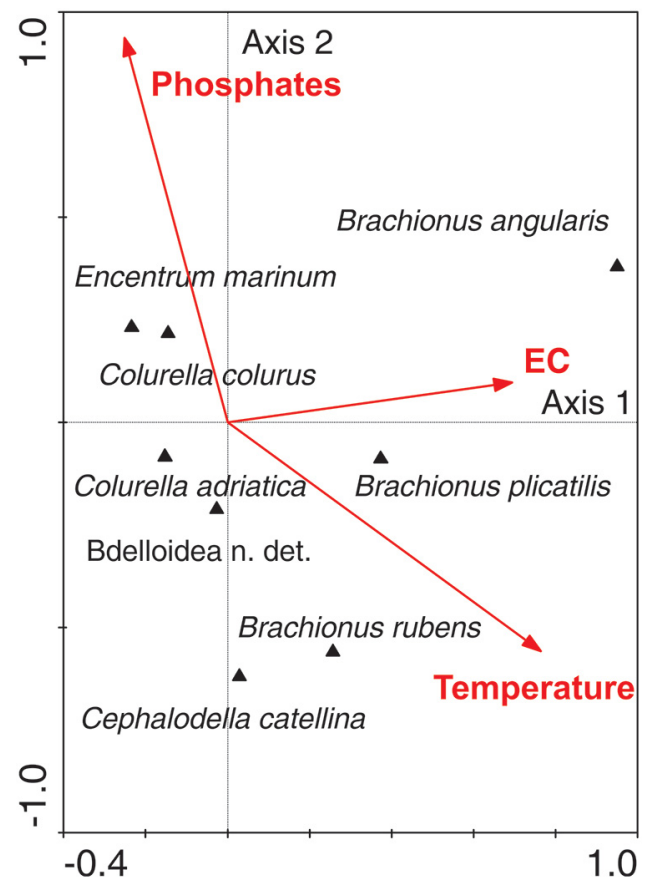

Fig. 5. Ordination diagram (biplot) based on a canonical correspondence analysis (CCA) of the rotifer data and environmental variables (statistically significant) of the Bolina River.

to stagnant waters (Bielańska-Grajner and Cudak, 2014; Bielańska-Grajner et al., 2014a; Pociecha et al., 2018; Żurek et al., 2018). Although the rotifer communities in naturally strongly saline running waters have been the subject of researches, these studies have primarily concerned estuaries. Scientists have reported the occurrence of more rotifer taxa in estuaries than in the Bolina River. For example, 16 rotifer 
species were recorded in the Mossoró River Estuary (salinity up to $50 \mathrm{~g} \mathrm{~L}^{-1}$ ) (Abdul et al., 2016), 25 rotifer taxa in the Samborombón River (salinity up to $4485 \mu \mathrm{S} \mathrm{cm}^{-1}$ ) and in the Vembanad Estuary (salinity up to 33\%o) (Modenutti, 1998; Retina et al., 2015). A similar number of rotifer taxa to that in the Bolina River, i.e. 12 taxa, occurred in a tropical coastal estuary in Nigeria (mean salinity $537.17 \mu \mathrm{S} \mathrm{cm}^{-1}$ ) (Abdul et al., 2016). In the strongly naturally saline Nile River Estuary (salinity up to 40 PSU), El-Tohamy et al. (2018) reported a lower number of rotifer taxa in the planktonic samples (six taxa) than in the Bolina River; however, the average density of the planktonic rotifers was much lower in the Bolina River than that in the Nile River Estuary. According to Neschuk et al. (2002), 65 taxa of planktonic rotifers were recorded in a saline lowland river, i.e. the Salado River and its tributaries (Argentina), which has an average salinity up to $5367.6 \mu \mathrm{S} \mathrm{cm}^{-1}$, despite the fact that the flow velocity in this river was almost twice as high as in the Bolina River. By contrast, ten taxa of planktonic rotifers were recorded in the Bolina River. However, the salinity of the Bolina River was higher and it ranged up to 33.55 PSU. For comparison, 65 taxa of rotifers occurred in naturally saline reservoirs that had a salinity up to $2500 \mu \mathrm{S} \mathrm{cm}^{-1}$ (Claps et al., 2011), 13 taxa in acidic pyrite mine pit lake that had a salinity up to $3400 \mu \mathrm{S} \mathrm{cm}^{-1}$ (Pociecha et al., 2018), whereas 8-15 rotifer taxa occurred in the anthropogenically strongly saline reservoirs with a maximum salinity of $63,456 \mu \mathrm{Scm}^{-1}$ (settling ponds) (BielańskaGrajner and Cudak, 2014).

This survey showed that the maximum value of the Shannon-Wiener index that was calculated for the rotifer communities ranged up to 2.14. Similar results have been obtained in acidic pyrite mine pit lakes (Pociecha et al., 2018). By contrast, the value of the Shannon-Wiener index for the rotifer communities of the most saline sections of the Vembanad estuary was higher. However, the value of the $H^{\prime}$ index for the rotifer communities of a large monsoonal estuary (Cochin backwaters) only ranged up to 1.7 (Anjusha et al., 2018).

Our results showed that in an urban river with underground saline mine water discharge (the Bolina River), the highest number of rotifer species was represented by the genus Brachionus. A similar relationship has been observed in naturally and anthropogenically saline rivers and water reservoirs (including estuaries and lakes) (Modenutti and Claps, 1988; Green, 1993; Neschuk et al., 2002; Arora and Mehra, 2009; Battauz et al., 2013; Anjusha et al., 2018). Similar to the Bolina River, Brachionus species not only dominated in the rotifer communities in the Bolina River but also in the Mossoró River Estuary (Medeiros et al., 2010) as well as in the saline lowland Salado River (Neschuk et al., 2002). Among the species of the Brachionus genus, the rare halophilous species Brachionus plicatilis occurred in the Bolina River. To date, B. plicatilis has only been recorded in the coal mine settling ponds and mining subsidence reservoirs of Upper Silesia, Poland (Bielańska-Grajner and Cudak, 2014; Bielańska-Grajner et al., 2014a). B. plicatilis inhabits saline waters and is also commonly cultivated for aquaculture purposes (Fontaneto et al., 2006). Based on the canonical correspondence analysis (CCA), our results confirmed that the density of B.plicatilis positively correlates with EC.
The results of the CCA ordinations showed that EC, water temperature and the concentration of phosphates were the parameters that were most associated (statistically significant) with the distribution of the rotifers in the Bolina River. The surveys of Korstad et al. (1989) and Sarma and Nandini (2019) showed that rotifers can exploit different food sources. The diet of rotifers consists of detritus, diatoms, protozoans or algae. Brachionid rotifers consume different seston size fractions including algae. In streamwater, phosphorus occurs as orthophosphates $\left(\mathrm{PO}_{4}{ }^{3-}\right)$, which are dissolved in the water and attached to inorganic particles in a suspension as well as dissolved organic molecules and in a particulate organic form primarily in bacteria and detrital particles (Allan and Castillo, 2007). Algae directly assimilate orthophosphates, whereas other forms of phosphorus must be transformed into orthophosphates before they can be assimilated. A higher concentration of orthophosphate in the water has an influence on the increase in the abundance of algae, which in turn provides food for rotifers. Thus, a positive relationship between the distribution of rotifers and the concentration of phosphates may be explained by their food preferences. This result confirmed the survey of Neschuk et al. (2002), which showed a positive correlation between the rotifer density and an increase in the concentration of phosphates in the Salado River.

The most important factor for the survival and reproduction of rotifers, in addition to the quality and quantity of food, is temperature (Bielańska-Grajner et al., 2014a). There is a clear relationship between temperature and the development of rotifers. The response of rotifers to temperature is primarily a result of the response of individual species to the developmental and reproductive timing (Miracle and Serra, 1989). For example, Brachionus plicatilis can develop at temperatures above $10{ }^{\circ} \mathrm{C}$ (Nagata, 1985). In the Bolina River, only three species were recorded in winter (temperature 9.1-10.5 ${ }^{\circ} \mathrm{C}$ ): Colurella adriatica, C. colurus and Encentrum marinum. Only E. marinum does not occur in waters below $10{ }^{\circ} \mathrm{C}$ (Jersabek and Leitner, 2013). Our results show that an increase in the temperature of the water in summer of up to $29.1{ }^{\circ} \mathrm{C}$ affected the development of the plankton rotifers such as B.plicatilis and B. rubens.

As result of the saline mine water discharge into the Bolina River, a very high value of EC was recorded in the lower course compared to the upper course. This survey revealed a negative correlation between the distribution of rotifers and EC except for the halophilous species, i.e. Brachionus plicatilis. Moreover, the median density, number of rotifer taxa and diversity decreased with an increase in EC in the lower course. Such a relationship was not observed in the Salado River because the highest mean density was recorded in the middle section and the lowest in the headwaters. However, the EC of the Salado River was above $5300 \mu \mathrm{S} \mathrm{cm}^{-1}$ (Neschuk et al., 2002). A similar relationship, i.e. a decrease in the density and number of rotifer taxa with an increase in EC (salinity), was observed in the Vembanad Estuary (Retina et al., 2015) and in the Mossoró River Estuary (Medeiros et al., 2010).

The low species richness and diversity of rotifers in the Bolina River is connected with the high value of EC because salinity is a limiting factor for rotifers (Green, 1993; Modenutti, 1998). The low densities of rotifers in the planktonic samples may have been caused by a lack of 
available food. For comparison, the densities of the rotifers in the periphytic samples (macrophytes and diatom aggregations) were much higher. Therefore, a positive correlation between the distribution of rotifers and the concentration of phosphates in the water was observed. According to Bielańska-Grajner et al. (2015), the rotifers that are associated with aquatic vegetation were also recorded in the planktonic samples. Our results confirmed that Colurella adriatica and C. colurus were recorded in both the planktonic and periphytic samples. However, the density of C. adriatica and C. colurus was higher in the periphytic samples. The occurrence of these species in the planktonic samples may be explained by their being washed out of the macrophytes (tychoplankton). On the other hand, planktonic rotifers were found in the periphytic samples, which were probably related to the low flow velocity and the availability of food among the macrophytes and diatom aggregations.

\section{Conclusions}

The rotifer communities in the Bolina River are affected by several environmental factors including EC, water temperature, the concentration of phosphates and the availability of food sources. A strongly negative influence of salinity on the rotifer community structure was observed in the studied river, which is currently one of the most severely anthropogenically salinised rivers in the world. The increase in the EC (salinity) in the lower course as a result of salty mine water discharge into the Bolina River was reflected by a decrease in the median density, number of rotifer taxa and diversity index $H^{\prime}$. A comparison with the rotifer community structure in other saline habitats is problematic because scientists determine salinity using different units, e.g. EC, TDS or the concentration of chlorides in the water. The Bolina River is a unique habitat for halophilic rotifers and the site of the occurrence of the rotifers that can also develop in the winter.

Acknowledgements. The authors are deeply indebted to the Editor-in-Chief and to the anonymous reviewers for their valuable suggestions and comments, which significantly improved the quality of this manuscript. The authors are also grateful to Ms. Michele L. Simmons, B.A., University of Silesia, Faculty of Biology and Environmental Protection, Katowice, Poland, for improving the English style.

\section{References}

Abdul WO, Adekoya EO, Ademolu KO, Omoniyi IT, Odulate DO, Akindokun, TE, Olajide AE. 2016. The effects of environmental parameters on zooplankton assemblages in tropical coastal estuary, South-west, Nigeria. Egypt J Aquat Res 42: 281-287.

Akopian M, Garnier J, Pourriot R. 2002. Zooplankton in an aquatic continuum: From Marne River and its reservoir to the Seine Estuary. C R Biol 325: 807-818.

Allan JD, Castillo MM. 2007. Stream ecology: Structure and function of running waters. Dordrecht: Springer, $436 \mathrm{p}$.

Anjusha A, Jyothibabu R, Jagadeesan L, Arunpandi N. 2018. Role of rotifers in microzooplankton community in a large monsoonal estuary (Cochin backwaters) along the west coast of India. Environ Monit Assess 190: 295.
Arora J, Mehra NK. 2009. Seasonal dynamics of zooplankton in a shallow eutrophic, man-made hyposaline lake in Delhi (India): role of environmental factors. Hydrobiologia 626: 27-40.

Battauz YS, Jose SB, Paggi JC, Romano M, Barberis IM. 2013. Zooplankton characterisation of Pampean saline shallow lakes, habitat of the Andean flamingoes. J Limnol 72: 531-542.

Bielańska-Grajner I, Cudak A. 2014. Effects of salinity on species diversity of rotifers in anthropogenic water bodies. Pol $J$ Environ Stud 23: 27-34.

Bielańska-Grajner I, Cudak A, Biała A, Szymańczak R, Sell J. 2014a. Role of spatial and environmental factors in shaping the rotifer metacommunity in anthropogenic water bodies. Limnology 15: 173-183.

Bielańska-Grajner I, Ejsmont-Karabin J, Iakovenko N. 2014 b. Wrotki: (Rotifera. Bdelloidea). Łódź: Wydawnictwo Uniwersytetu Łódzkiego, $154 \mathrm{p}$.

Bielańska-Grajner I, Ejsmont-Karabin J, Radwan S. 2015. Rotifers. Rotifera Monogononta. Łódź: Wydawnictwo Uniwersytetu Łódzkiego, $582 \mathrm{p}$.

Bukowski M, Gąska J, Jackl F, Karaczun Z, Kassenberg A, Pankowiec A, Śniegocki A, Śpionek A, Szpor A. 2013. 2050.pl podróż do niskoemisyjnej przyszłości. Warszawa: WISE, 220 p.

Cañedo-Argüelles M, Kefford BJ, Piscart C, Prat N, Schäfer RB, Schulz CJ. 2013. Salinisation of rivers: An urgent ecological issue. Environ Pollut 173: 157-167.

Chindah A. 2004. Responses of periphyton community to salinity gradient in tropical estuary, Niger Delta. Pol J Ecol 52: 83-89.

Claps MC, Gabellone NA, Benitez HH. 2011. Seasonal changes in the vertical distribution of rotifers in a eutrophic shallow lake with contrasting states of clear and turbid water. Zool Stud 50: 454-465.

Derry AM, Prepas EE, Hebert PDN. 2003. A comparison of zooplankton communities in saline lake water with variable anion composition. Hydrobiologia 505: 199-215.

Directive. 2000. Directive 2000/60/EC of the European Parliament and of the Council of 23 October 2000 establishing a framework for Community action in the field of water policy. Official Journal of the European Communities L327: 1-72.

El-Tohamy WS, Hopcroft RR, Abdel Aziz NEM. 2018. Environmental determinants of zooplankton community in the Damietta Estuary of the Nile River, Egypt. Pak J Zool 50: 1785-1798.

Fontaneto D, Smet WH, Ricci C. 2006. Rotifers in saltwater environments, re-evaluation of an inconspicuous taxon. J Mar Biol Assoc UK 86: 623-656.

Górny M, Grüm L. 1981. Metody stosowane w zoologii gleby. Warszawa: PWN, 483 p.

Goździejewska AM, Skrzypczak AR, Paturej E, Koszałka J. 2018. Zooplankton diversity of drainage system reservoirs at an opencast mine. Knowl Manag Aquat Ecosyst 419: 33-42.

Green J. 1993. Zooplankton associations in East African lakes spanning a wide salinity range. Hydrobiologia 267: 249-256.

Hammer UT. 1993. Zooplankton distribution and abundance in saline lakes of Alberta and Saskatchewan, Canada. Int J Salt Lake Res 2: 111-132.

Harat A, Grmela A. 2008. Impact of mine water from the Upper Silesian Coal Basin areas on change quality of water in Olza River in years 2000-2007. Nat Environ Monit 9: 57-62.

Hermanowicz W, Dojlido J, Dozańska W, Koziorowski B, Zerbe J. 1999. Physical and chemical studies of water and wastewater. Warszawa: Arkady, $556 \mathrm{p}$.

Jersabek CD, Leitner MF. 2013. The Rotifer World Catalog. World Wide Web electronic publication. Available from http://www. rotifera.hausdernatur.at/ (Accessed 09.04.2019). 
Jin C. 2008. Biodiversity dynamics of freshwater wetland ecosystems affected by secondary salinisation and seasonal hydrology variation: A model-based study. Hydrobiologia 598: 257-270.

Kaya M, Fontaneto D, Segers H, Altindag A. 2010. Temperature and salinity as interacting drives of species richness of planktonic rotifers in Turkish continental waters. J Limnol 69: 297-304.

Korstad J, Olsen Y, Vadstein O. 1989. Life history characteristics of Brachionus plicatilis (Rotifera) fed different algae. Hydrobiologia 186: 43-50.

Masson-Delmotte V, Zhai P, Pörtner HO, Roberts D, Skea J, Shukla PR, Pirani A, Moufouma-Okia W, Péan C, Pidcock R, Connors S, Matthews JBR, Chen Y, Zhou X, Gomis MI, Lonnoy E, Maycock T, Tignor M, Waterfield T. 2018. IPCC, 2018: Global warming of $1.5^{\circ} \mathrm{C}$. An IPCC Special Report on the impacts of global warming of $1.5{ }^{\circ} \mathrm{C}$ above pre-industrial levels and related global greenhouse gas emission pathways, in the context of strengthening the global response to the threat of climate change, sustainable development, and efforts to eradicate poverty. Geneva, Switzerland: World Meteorological Organization, $562 \mathrm{p}$.

McCune B, Grace JB. 2002. Analysis of ecological communities. MjM Software Design. Oregon, USA: Gleneden Beach, 300 p.

Medeiros AMA, Barbosa JEL, Medeiros PR, Rocha RM, Silva LF. 2010. Salinity and freshwater discharge determine rotifer distribution at the Mossoró River Estuary (Semiarid Region of Brazil). Braz J Biol 70: 551-557.

Miracle MR, Serra M. 1989. Salinity and temperature influence in rotifer life history characteristics. Hydrobiologia 186: 81-102.

Modenutti BE. 1998. Planktonic rotifers of Samborombón River Basin (Argentina). Hydrobiologia 387/388: 259-265.

Modenutti B, Claps M. 1988. Monogononta rotifers from plankton and periphyton of pampasic lotic environments. Limnologica 19: 167-175.

Nagata WD. 1985. Long-term acclimation of a parthenogenetic Strain of Brachionus plicatilis to subnormal temperatures. I. Influence on size, growth, and reproduction. Bull Mar Sci 37: 716-725.

Neschuk N, Claps M, Gabellone N. 2002. Planktonic rotifers of a saline-lowland river: The Salado River (Argentina). Ann Limnol 38: 191-198.

Nielsen DL, Brock MA, Vogel M, Petrie R. 2008. From fresh to saline: A comparison of zooplankton and plant communities developing under a gradient of salinity with communities developing under constant salinity levels. Mar Freshw Res 59: 549-559.

Onwudinjo CC, Egborge ABM. 1994. Rotifers of Benin River, Nigeria. Hydrobiologia 272: 87-94.

Pinder AM, Halse SA, Mcrae JM, Shiel RJ. 2005. Occurrence of aquatic invertebrates of the Wheatbelt region of Western Australia in relation to salinity. Hydrobiologia 543: 1-24.

Pociecha A, Bielańska-Grajner I. 2015. Large-scale assessment of planktonic organisms biodiversity in artificial water reservoirs in Poland. Kraków: IOP PAN, 269 p.
Pociecha A, Bielańska-Grajner I, Szarek-Gwiazda E, Wilk-Woźniak E, Kuciel H, Walusiak E. 2018. Rotifer diversity in the acidic pyrite mine pit lakes in the Sudety Mountains (Poland). Mine Water Environ 37: 518-527.

Remane A, Schlieper C. 1971. The biology of brackish waters. New York: Wiley Interscience, $372 \mathrm{p}$.

Retina IC, Aska CV, Suson PS, Nandan SB. 2015. Species Diversity and community assemblage of planktonic rotifers from Vembanad Estuary-Kerala, India. Int J Oceanogr Mar Ecol Syst 4: 1-15.

Sarma SSS, Nandini S. 2019. Comparative population dynamics of six brachionid rotifers (Rotifera) fed seston from a hypertrophic, high altitude shallow water body from Mexico. Hydrobiologia $1-11$.

Sarma SSS, Nandini S, Morales-Ventura J, Delgado-Martínez I, González-Valverde L. 2006. Effects of $\mathrm{NaCl}$ salinity on the population dynamics of freshwater zooplankton (rotifers and cladocerans). Aquat Ecol 40: 349.

Schallenberg M, Hall CJ, Burns CW. 2003. Consequences of climateinducted salinity increases on zooplankton abundance and diversity in coastal lakes. Mar Ecol Prog Ser 251: 181-189.

Segers H. 2007. Annotated checklist of the rotifers (Phylum Rotifera), with the notes on nomenclature, taxonomy and distribution. Zootaxa 1564: 1-104.

Tarkowska-Kukuryk M. 2013. Periphytic algae as food source for grazing chironomids in a shallow phytoplankton-dominated lake. Limnologica 43: 254-264.

Ter Braak CJF, Šmilauer P. 2002. CANOCO Reference manual and CanoDraw for Windows User's Guide: Software for Canonical Community Ordination (version 4.5), 2nd ed. Ithaca, New York: Microcomputer Power, $500 \mathrm{p}$.

Tiwary RK. 2001. Environmental impact of coal mining on water regime and its management. Water Air Soil Pollut 132: 185-199.

Wallace RL, Snell TW. 2001. Phyllum rotifera. In: Thorp JH, Covich AP, (eds). Ecology and classification of North American freshwater invertebrates. New York: Academic Press, pp. 195-254.

Walsh EJ, Schröder T, Wallace RL, Riosarna JV, Rico-Martínez R. 2008. Rotifers from selected inland waters in the Chihuahuan Desert of Mexico. Saline Syst 4: 7.

Williams WD. 1987. Salinisation of rivers and streams: an important environmental hazard. Ambio 16: 180-185.

Williams WD. 2001. Anthropogenic salinisation of inland waters. Hydrobiologia 466: 329-337.

Zakaria HY, Radwan AA, Said MA. 2007. Influence of salinity on zooplankton community in El-Mex Bay, Alexandria, Egypt. Egypt J Aquatic Res 33: 52-67.

Żurek R, Diakiv V, Szarek-Gwiazda E, Kosiba J, Wojtal AZ. 2018. Unique pit lake created in an opencast potassium salt mine (Dombrovska Pit Lake in Kalush, Ukraine). Mine Water Environ 37: $456-469$.

Cite this article as: Halabowski D, Bielańska-Grajner I, Lewin I. 2019. Effect of underground salty mine water on the rotifer communities in the Bolina River (Upper Silesia, Southern Poland). Knowl. Manag. Aquat. Ecosyst., 420, 31. 